\title{
Towards making willows pilot species for coppicing production
}

\author{
by Urban Gullberg
}

Long and short term breeding of willows for energy production in Sweden and basic research related to these activities is presented. The strategy is to concentrate on one species, $S$. viminalis, to functionally separate long and short-term breeding and to emphasize general biological research on Salix. In the long term breeding we have a sub-divided breeding population where we aim for inbreeding in the sublines. The selection of cultivars is based on both family and individual selection and cloning is used in this process. The basic research is concerned with the components of growth, the genetics of small populations and host-parasite interaction.

Key words: genetics, long term breeding, S. viminalis, subdivided breeding population, components of growth, small populations, host-parasite interaction.

\section{Introduction}

We are in the fortunate position of breeding Salix, a short rotation energy crop, when both economic and political forces are in favour of this idea. Thus we are acting in a context where, it seems, promising contributions are made in most of the important subject areas, from the basic biology of the plant material to the creation of a market for this energy product.

The program for energy forestry based on coppicing species has been ongoing in Sweden for nearly 20 years. It was started in the mid-seventies on the initiative of Gustaf Sirén, at that time professor of forest regeneration. The idea was to create an alternative to oil. Energy forestry has since that time been one of the options in the planning of an energy policy in Sweden. Today, Salix grown for coppicing on agricultural land is looked upon as an alternative that could give more than $10 \%$ of Sweden's heat energy some twenty to thirty years from now (Anonymous 1992). The policy to change the utilisation of farmland away from cereals makes such forecasts realistic and the present data show that Salix is an interesting option for the farmer (Johansson et al. 1992).

The basic reason for using Salix as an energy crop is its high production of wood in young shoots, which makes it possible to get an early return on the investments made in the establishment of a cultivation (Christersson et al. 1993). Other attractive features are its capacity for easy propagation and for producing shoots after coppicing. Genetically, Salix is also very attractive with its short generation time, one to two years, no obvious problems with aging when propagated by cuttings and a comparatively small amount of $\mathrm{DNA}^{2}$. It also seems that transgenic plants

Swedish University of Agricultural Sciences, Department of Plant Breeding Research, Box 7003, 75007 Uppsala, Sweden.
L'amélioration génétique à court et à long terme des saules à des fins de production énergétique en Suède ainsi que la recherche de base rattachée à ces activités sont présentées dans cet article. La stratégie visée est de se concentrer sur une espèce $S$. viminalis, de séparer fonctionnellement l'amélioration génétique à court et à long terme et à mettre en valeur la recherche biologique générale sur les Salix. Au niveau de l'amélioration génétique à long terme, nous avons une population à améliorer subdivisée où nous tentons d'interféconder les lignées secondaires. La sélection des cultivars est établie à la fois sur la sélection de la famille et des individus et nous utilisons le clonage lors de ce processus. La recherche de base touche les composantes de la croissance, la génétique des petites populations et les interactions hôte-parasite.

Mots clés: génétique, amélioration génétique à long terme, $S$. viminalis, population à améliorer subdivisée, composantes de la croissance, petites populations, interaction hôte-parasite. are within reach after some tuning of the present technique (Grönroos et al. 1989; Vahala et al. 1989; Vahala and Eriksson 1991; Vahala et al. 1993).

The cultivation of Salix for energy forestry demands a well prepared soil that contains a minimum of weeds the first year. Twenty $\mathrm{cm}$ long cuttings are planted in the spring, approximately two per $\mathrm{m}^{2}$, and the planting is coppiced after three to five years. Harvesting takes place in winter. For the moment we plan on using the roots for twenty years before we replant, therefore a stool will be coppiced on average six times before the stools are removed through plowing. Rapid genetic improvement might make re-planting more often a better option. Machinery for planting and harvesting has been developed and during the last couple of years a considerable improvement in technological productivity has occurred (Danfors and Nordén 1992).

The production of cuttings for cultivation is also an

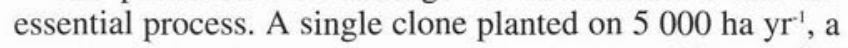
possible situation within 20 to 30 years, will require 100 million cuttings. So far cuttings are produced as for the energy cultivations except that the shoots are harvested when they are one or two years old and it is also required that the shoots have certain minimum qualities so that they could be made into cuttings. Special equipment for harvesting has been developed. To reach 100 million cuttings from the later stages in the clone test takes three to five years with this technique.

The logical framework for the introduction of willows as an energy crop depends on cooperation between farmers, extension services, commercial companies and researchers. At present the major part of the research is made in Sweden at the Swedish University of Agricultural

${ }^{2}$ David Clapham, personal communication. 
Sciences. The Swedish Institute of Agricultural Engineering is taking part in the development of machinery and Svalöf Weibull $A B$ in the breeding and marketing of new material. Several companies are involved in producing machinery and cultivars and in promoting the idea of energy forestry among farmers. The extension service has earmarked money for willows to advise farmers. Farmers get subsidies for plantation, until the middle of the nineties. The acreage grown has been increasing rapidly the last couple of years and in 1992, 3000 ha were planted. One forecast (Anonymous 1992) estimates an acreage of several hundred thousand hectares with an average yearly production of 12 tonnes of dry matter per hectare.

\section{Breeding Strategy}

In the beginning, breeding was a part of an interdiciplinary project, within the Swedish University of Agricultural Sciences, for the development of energy forestry cultivation, but since the middle of the eighties the Department of Forest Genetics has been in charge. For the last five years, breeding has also been conducted in the private breeding company Svalöf Weibull AB. For the moment the project at the Department of Forest Genetics has a staff of approximately ten scientists and technicians and the Svalöf Weibull $\mathrm{AB}$ project is half that size.

In terms of breeding goals, the focus has been on intensive production of wood energy the whole time, but the development since the start in the seventies has meant a narrowing down both in material and cultivation sites. Initially, both poplar and willow species were tested and the idea was to use both agricultural land and bogs for cultivation. The early testing showed that the poplar clones were very vulnerable to disease and that many of the willow species were not. It also indicated that for willows a short rotation with three or four years between harvests seemed promising. Thus the program has concentrated on some ten willow species (Sirén et al. 1979). The early testing also showed that cultivation was difficult on bogs. At the same time the country's agricultural policy made the farmers look for new crops and, as noted above, they have shown interest in energy forestry. During recent years, therefore, nearly all emphasis has been put on breeding for planting on good agricultural land.

The general aim of the program for genetics and breeding is to make Salix a reliable crop for energy production and to keep an option open for other purposes as, for example, the control of environmentally dangerous deposits. Comparisons with agricultural crops show that to make Salix reliable for cultivation, we need to increase the research volume. Our strategy for doing this is to make genetic research on Salix attractive. On the one hand we aim to develop good basic research within a limited number of subjects and thereby attract other students or research groups to use Salix in their work. On the other hand, we want to integrate students or research groups with us by the routine provision of a wide range of genetically well characterised and well maintained material. The functional components of our program are basic research and long-term and short-term breeding and they are interrelated as described by Gullberg and Kang (1985). Key issues are:

\footnotetext{
- Concentration on one species since this will give us the
}

possibility to utilize the within species variation and to establish the potential of this species. We are reluctant to give too much emphasis to species hybrids since it will be difficult to build up knowledge of these before we know the biology of the single species. When the questions we ask can be answered by using species outside the genus Salix, we shall not hestitate to do so.

- Separation of short and long-term breeding so that we can afford to look into problems that need more than a couple of generations of breeding to be solved.

- Study the general biology of Salix so that biology students become interested in the species and contribute to the understanding of its mechanisms. We believe that a Salix species, with its low level of domestication, will be an excellent tool for the understanding of evolutionary genetics problems. In addition to an insight into the natural populations, the breeding will provide us with means of uncovering the causes behind the patterns observed in nature.

\section{Genetic Material Species}

The results so far (Ager et al. 1986; RönnbergWästljung and Thorsén 1988) have led us to concentrate on Salix viminalis $\mathrm{L}$. and in addition to pay attention to Salix dasyclados Wimmer and Salix schwerinii E Wolf. These species are native south east of Sweden, S. viminalis from Germany and far into Russia, $S$. dasyclados from Poland and eastwards and $S$. schwerinii in the central parts of Russia (Skvortsov 1968). For many years there have been contradictory statements about the systematics of $S$. dasyclados (Stott 1984), but we have been able to classify most of the material in our collection into the taxa $S$. dasyclados Wimmer and $S . \times$ smithiana Willd. (Larsson and Bremer 1991). There are conflicting statements about the parents to $S$. $\times$ smithiana, but there is strong evidence that they are $S$. caprea and S. viminalis (Larsson and Bremer 1991). Most of the $S$. dasyclados clones of Polish origin are provisionally classified as var. baltica. Through isozyme analysis ${ }^{3}$ we have also confirmed earlier cytological studies (Chmelar 1979) that there are polyploid S. dasyclados.

We shall also look into the possibility of making hybrids based on the above species but hybrids are not emphasized. So far we have managed to make hybrids between $S$. viminalis and $S$. dasyclados but only when $S$. viminalis is the male. We have also produced hybrids between $S$. viminalis and S. caprea, S. $\times$ smithiana and S. schwerinii.

To create a wide range of genetic material, we have collected cuttings from natural populations, developed a subdivided breeding population and screened for recessive mutations in inbred families and for extreme phenotypes in clonal trials. The basic idea is to establish a collection of genetically diverse material in order to understand, by means of contrasting genotypes, the biology of important phenomena within Salix.

\section{Collections}

Material from forty willow species was brought to Sweden from different collections in central Europe and

\footnotetext{
${ }^{3}$ Johanna Thorsén, personal communication.
} 
North America in the seventies. In addition, a thorough collection was made within Sweden in the late seventies by announcing a competition all over the country for the tallest willow shoot (Sirén et al. 1979). One result was that several hundred accessions of $S$. viminalis and $S$. dasyclados were obtained and many of them are in the breeding population.

Starting in 1985, we made systematic collections of willows from natural populations of $S$. viminalis and $S$. dasyclados, 900 and 100 clones respectively. The collection aimed at finding most clones that existed in Sweden and a stratified sample along the river banks in Austria, Germany and Poland. Through Svalöf Weibull $\mathrm{AB}$ we also have $S$. viminalis and $S$. schwerinii from central Russia. The natural populations have been characterized for isozymes (Thorsén et al. 1993) and for growth capacity, growth form and disease resistance in a common garden experiment.

\section{Breeding Population}

We have developed subdivided breeding populations (Fig. 1) for $S$. viminalis and $S$. dasyclados with the idea of creating genetic variation by recurrent selection of different breeding populations towards different breeding goals (Eriksson et al. 1985; Gullberg and Kang 1985; Kang and Nienstaedt 1987). We have opted for the smallest possible subpopulation, that is $\mathrm{N}_{\mathrm{e}}=2$ since Salix is dioecious, to purge lethal or sublethal genes and to cause recessive alleles to be expressed. So far, after two generations of brother-sister mating, we have not observed any serious effects on viability, but the sex determination in S. viminalis has caused a problem. From the crosses so far analysed, we have some support for there being two independently segregating autosomal genes that determine sex and that females are produced when there is a dominant gene in both loci, all other cases giving males ${ }^{4}$. This can lead to families where all the offspring are females which has occurred for some of the subpopulations so that they cannot be continued.

In the inbred lines we have screened for interesting forms. The idea is to catch mutants that cause a disturbance to a developmental process. This gives us a possibility to understand the normal development by using the fact that rare recessive alleles with low viability will be a high proportion of an inbred family. For the moment we have found two deviating flower variations that could be useful to future research and breeding ${ }^{5}$. One is early flowering, that is, producing either male or female flowers after five to six weeks from sowing. The segregation in $F_{1} \times F_{1}$ crosses and in backcrosses shows that there is a lethal gene involved, but that the flowering pattern could be inherited in a simple Mendelian fashion. We plan to use these genes to develop material for rapid cycling Salix that, for example, could be used for disease testing. The other form gives monoeocious plants in a high frequency in one inbred family.

\section{Selection of Cultivars}

The program for developing cultivars for farmers is a joint effort between the Swedish University of Agriculture

${ }^{4}$ Urban Gullberg, personal communication.

${ }^{s}$ Urban Gullberg, personal communication.

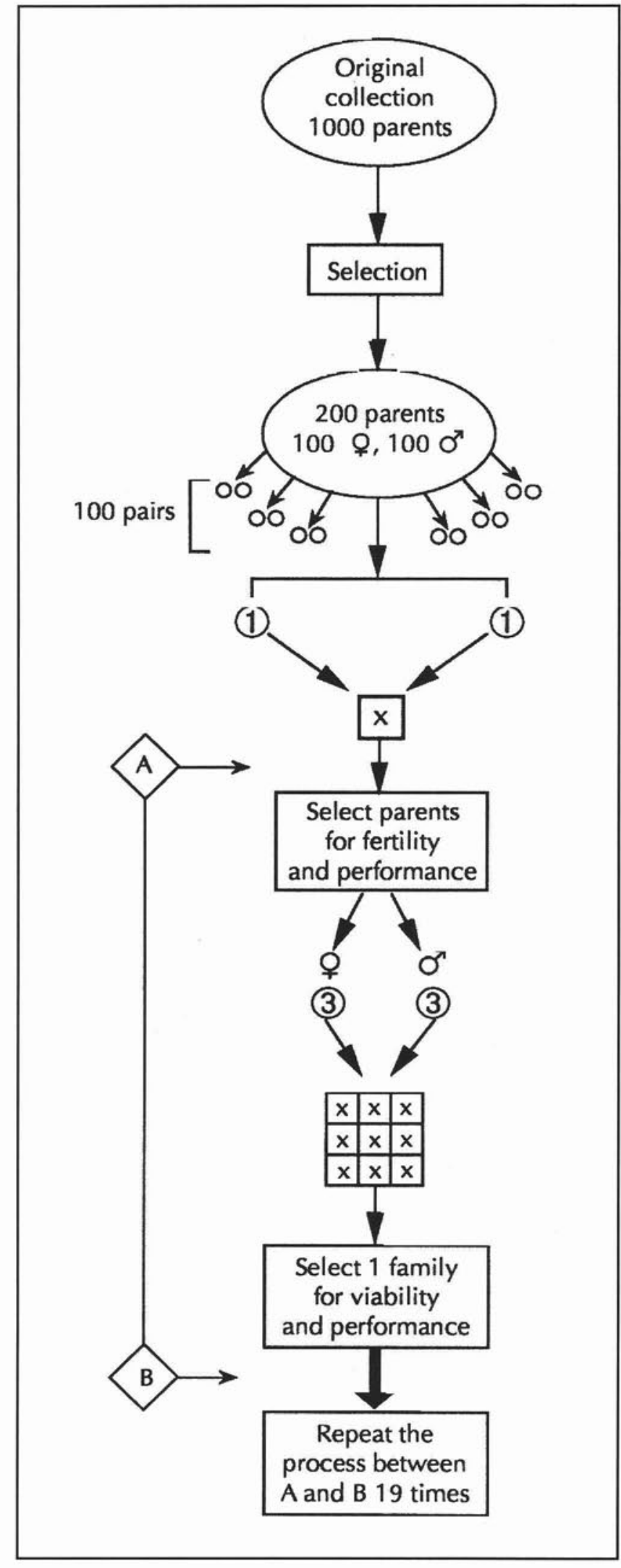

Figure 1. A full-sib crossing scheme for developing inbred lines while selecting for performance. $\mathrm{x}$ represents the crossings and each family consists of 25 to 40 individuals (adapted from Eriksson et al. 1984). 

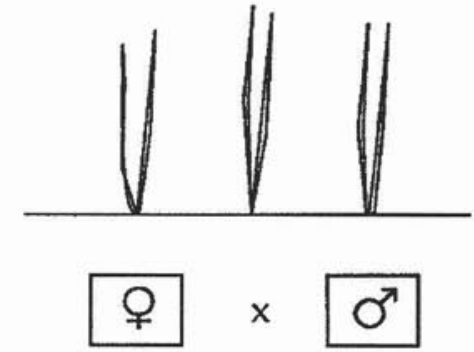

U
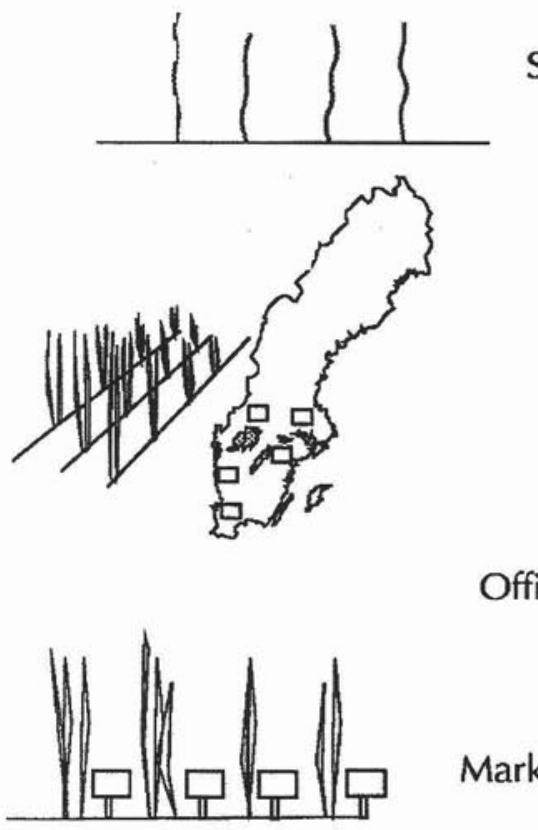

SLU SW

Select parents
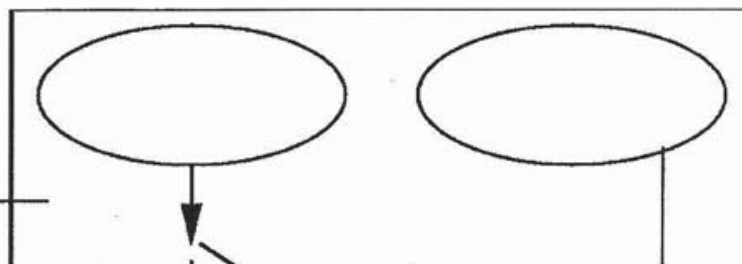

Select seedlings

Crossings

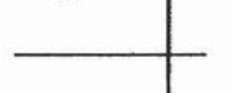

Select clones
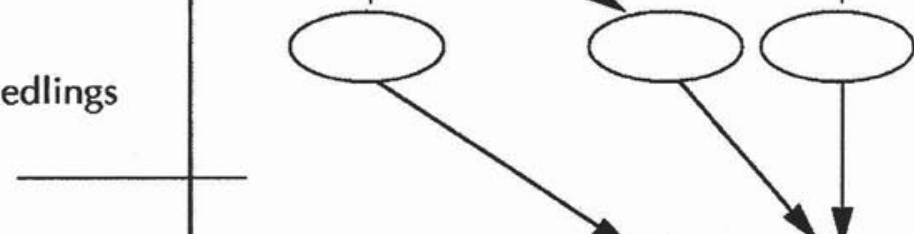

Official clone tests

Marketing of clones

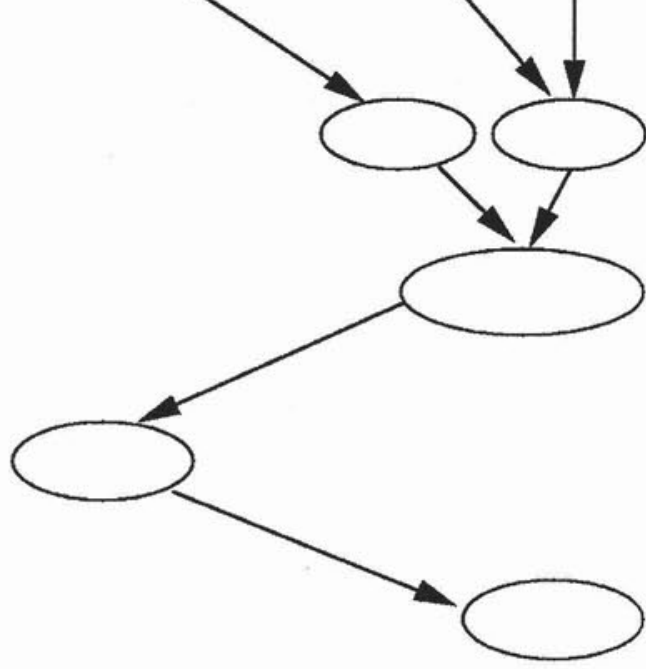

Figure 2. Scheme for production of improved material showing the divisions of labour between the breeding group at Swedish University of Agriculture (SLU) and Svalöf Weibull AB (SW).

and private breeders. For the moment Svalöf Weibull AB is the dominating private breeder and Figure 2 gives an idea of how we have divided the task. We start from material in the breeding population by crossing inbred lines, but so far other sources also have been used. Selection takes place both in the generative and vegetative phase (Gullberg 1988, 1989a, 1989b). In the generative phase we make recurrent selection. In the vegetative phase we have had two or three steps that altogether take six to ten years. The first step consists of many, 200 to 500 , clones that are planted in single-tree-plots, the last with the few best clones in large plots and on several sites. Many of today's commercial clones have only passed the vegetative phase. The first population in which we have made recurrent selection is started from thirty well performing clones from the earliest clone collections, and material from its first generation has passed the vegetative phase and is now introduced as comercial clones.

A set of trials, based on factorial crossing, was established in order to estimate genetic variances and covariances and genotype-environment interaction. The trial established in 1987 is a $5 \times 6$-factorial grown on five sites. In 1988 we established a $8 \times 8$ factorial on four sites and in 1990 two $10 \times 64$ factorials on one site. The trial established in 1988 will be studied over several coppicing cycles. So far we have estimates of variance components ready and they tell us that the heritabilities for growth traits vary from 0.1 to $0.5^{6}$. One important finding is that flower production seems to be negatively correlated with biomass production.

We can also see a considerable genotype-environment interaction that we cannot relate to environmental factors.

${ }^{6}$ AnnChristin Rönnberg-Wästljung, personal communication. 
This means that we cannot classify the environment properly and cannot therefore develop an official cultivar test that is reliable unless we have it on many sites. To improve this situation we therefore have opted for a study where we get a set of clones on many sites in order to get hold of the underlying factors for the genotype-environment interaction. A set of clones will be distributed to commercial growers, for observation. With data from many sites we expect to get sufficient information to suggest an official test with few sites.

\section{Data Base}

A system composed of portable computers, bar code readers, label printers and a relational data base has been developed. It will take care of most of the information generated in breeding and research routines and will keep track of pedigrees and uniquely identify each plant material entered.

\section{Basic Research \\ Components of Growth}

We aim at using both traditional methods and the new gene technology to describe the genetic variation within the species and its close relatives. Our initial need is to get a general picture of the important growth characters and their relationship, but we shall gradually concentrate our resources on a few important characters that are also of general interest to the understanding of trees.

In the steady state cultivation we aim for a fixed growth speed in terms of biomass growth. The idea is to give reproducible conditions for studies of the growth process. Evaluation of this technique also implies that it would be possible to predict the relative shoot-root ratio of clones by observing only the shoot (Ågren and Ingestad 1987). In a study in an outdoor construction with close to steady state conditions in a low and high nutrient regime, we observed that the majority of the clones behaved as expected, that is, they had the same ranking with respect to above ground biomass growth in the two nutrient regimes?. Genotype by environment interaction was observed for a few entries which changed ranking drastically and these clones are thought to differ from the rest in their allocation pattern between shoots and roots, and could therefore be used in studies of the mechanisms behind the shoot-root allocation.

Another character of interest for intensive studies is growth phenology. We find this character important since its mechanism could be unique for woody species and we could therefore generate new information from Salix applying to trees generally that could not be developed on non-woody plants. So far we have observed spring and fall phenology and have observed a genetic variation at both ends of the season ${ }^{8}$.

\section{Multigeneration Breeding}

To understand the behaviour of small populations over generations is of importance to breeding and to the maintenance of threatened species, and we approach this subject from a breeding perspective.

${ }^{7}$ AnnChristin Rönnberg-Wästljung, personal communication.

${ }^{8}$ AnnChristin Rönnberg-Wästljung, personal communication.
We find it fruitful to look upon breeding as divided into two activities, long-term and short-term breeding (Gullberg and Kang 1985; Kang and Nienstaedt 1987). With shortterm breeding we mean activities that emphasize quick genetic change towards breeding goals that are of economic interest today. In contrast, long-term breeding is concerned with creating options for an unpredictable future and with preservation of genetic variation.

Questions related to long-term breeding are both concerned with the selection limit for one population or a group of populations towards a single goal and with the combinatorial effects when having different populations and several goals. For a single goal critical problems are the minimal sustainable population size for breeding, the pros and cons of a subdivided breeding population, the relation between intensity of selection and the loss of desirable alleles and the pros and cons for different methods for generation turnover. Questions of concern in relation to multiple goals are if and how they decrease the loss of desirable alleles and how different subpopulations should be combined when utilized in breeding. The genetic problems related to threatened species are in many ways similar to those of long-term breeding populations.

We have opted for approaching this field in both a theoretical and an empirical way. The theoretical work will have its starting point in the ideas developed by Kang and co-authors around selection limits and minimum viable population size (Kang 1983; Kang 1989; Kang and Namkoong 1988). To test the multigeneration theories we use rapid cycling Brassica, Salix and Pinus banksiana Lamb.

At this point the work centers around empirical tests on Brassica rapa $\mathrm{L}$. on the theoretical results on limits of selection (Svärd 1992) and on studies on lethal equivalents in S. viminalis (Kang et al. 1992) and their effect on minimum viable population size.

\section{Host-parasite Interaction}

As we cannot use pesticides in many situations in an energy plantation, we are considering biological, including genetical, means of controlling parasites.

Rust of a Melampsora spp. is a disease that can have drastic effects on energy plantations since it can cause very early leaf drop and, consequently, poor autumn hardening, which results in severe frost damage during the winter (Verwijst 1990). So far, we have studied the field resistance of S. viminalis (Gullberg and Ryttman 1993) and found a considerable genetic variation for resistance to the fungus that depends on the origin of the willows. In climate chamber tests with different isolates we have also found that differences in temperature regime will affect the ranking of the Salix clones with respect to resistance reaction (Åström at al. 1993).

In one of the sites of the factorial crossings mentioned earlier we were fortunate to get a fairly even attack of a gall midge (Dasineura margenimtorquens Bremi) and could find 13 out of 240 clones that were resistant to the insect (Strong et al. 1993). As a consequence of this observation we have built up a joint project with entomologists and cell biologists with the aim of understanding the mechanisms behind the gall midge/Salix interaction. 


\section{References}

Ager, A., A.C. Rönnberg-Wästljung, J. Thorsén and G. Sirén. 1986. Genetic improvement of willows for energy forestry in Sweden. Sw Univ of Agric Sciences, Dept of Ecology of Environmental Research. Report 43, 47 p.

Ågren, G.I. and T. Ingestad. 1987. Root:shoot ratio as a balance between nitrogen productivity and photosynthesis. Plant, Cell and Environment 10, 579-586.

Anonymous. 1992. Biobränslen för Framtiden - slutbetänkande av biobränslekom-missionen (Bioenergy for the future - report by a bioenergy commission appointed by the Swedish government). Statens offentliga utredningar 1992:90, Stockholm. 429 p. (Only in Swedish).

Åström, B., M. Ramstedt, U. Gullberg and L. Johansson. 1993. Pathogenecity and isozyme pattern of Swedish willow rust isolates - preliminary results. Proc of IEA meeting in Ireland, September 1992 (submitted).

Chmelar, J. 1979. The taxonomic importance of chromosome number in the genus Salix L. Lesnictvi 25: 411-415.

Christersson, L. L. Sennerby-Forsse and L. Zsuffa. 1993. The role and significance of woody biomass plantations in Sweden. The Forestry Chronicle (submitted).

Danfors B. and Nordén. 1992. Teknikutvärdering av energiskogsskördare (Technical evaluation of harvesters for energy forestry). Swedish Institute of Agricultural Engineering, Report 150 (Eng abstract).

Eriksson, G., U. Gullberg and H. Kang. 1984. Breeding strategy for short rotation woody species. In: Ecology and management of forest biomass production system. pp. 199-216. SLU, Dept. Ecol. and Env. Res., Report no. 15.

Grönroos, L., S. von Arnold and T. Eriksson. 1989. Callus production and somatic embryogenesis from floral explants of basket willow (Salix viminalis L.). J. Plant Physiol. 135: 558-566. Gullberg, U. 1988. Breeding of Salix as an energy crop, state of the Swedish program 1987. In: Proc. from willow breeding symposium, Uppsala August/September 1987, SLU, Dept. of For. Genetics. Research notes 41, pp. 7-15. Uppsala.

Gullberg, U. 1989a. Current Salix breeding in the Swedish University of Agricultural Sciences. Proc. IEA Task II joint workshop: willow breeding and biotechnology development. pp. 27-33. Long Ashton Research Station, Bristol, UK, 28 Sept.6 Oct., 1988.

Gullberg, U. 1989b. Växtförädling av Salix (Breeding of Salix), 1986-1989. SLU, inst f skogsgenetik. Rapp o Upps 42, 54pp. Uppsala.

Gullberg, U. and H. Kang. 1985. A model for tree breeding. Studia For Seuc 169. Uppsala. 8 p.

Gullberg, U. och H. Ryttman. 1993. Genetics of field resistance to Melampsora rust in Salix viminalis. European J. of Forest Pathology (in press).

Johansson, H., S. Ledin and L. Sennerby-Forsse. 1992. Practical energy forestry in Sweden; a commercial alternative for farmers. Paper presented at 7 th European Conference on Biomass and Environment, Agriculture and Industry, in Florence, October 1992.
Kang, H. 1983. Limits of artificial selection under balanced mating systems with family selection. Silvae Genetica 32: 188-195.

Kang, H. 1989. Inbreeding effective population size under some artificial selection schemes. II. Normal distribution of breeding values. Forest Science 35: 303-318.

Kang, H. and G. Namkoong. 1988. Inbreeding effective population size under some artificial selection schemes. I. Linear distribution of breeding values. Theor. Appl. Genet. 58: 181-191.

Kang, H. and H. Nienstaedt. 1987. Managing long-term tree breeding stock. Silvae Genetica 36: 30-39.

Kang, H., C. Hardner and U. Gullberg. 1992. Lethal equivalents in willow, Salix viminalis. Silvae Genetica 41, 110-117.

Larsson, G. and B. Bremer. 1991. Korgviden-nyttoväxter förr och nu. (The Salix viminalis group - useful plants then and now.) Svensk Bot. Tidskr. 85: 185-200. (Eng abstract).

Rönnberg-Wästljung, A.C. and J. Thorsén. 1988. Inter- and intraspecific variation and genotype $\times$ environment interaction in Salix alba L., S. dasyclados Wimm. and S. viminalis L. Scand. J. For. Res. 3: 449-463.

Sirén, G., T.-L. Lestander and L. Sennerby. 1979. Preliminary tests of fast growing Salix clones. Proc. of the meeting concerning poplars in France and Belgium. 17-22 Sept. 1979, pp. 162-177. Dorschkamp Research Institute for Forestry and Landscape Planning. Wageningen-Netherlands.

Skvortsov, A.K. 1968. Willows of the USSR. A taxonomic and geographic survey. Proc. of the Fauna and Flora of the USSR. Moscow Soc. Nat. New Series Botany Section, 15 (23). (English translation 1972. Ottawa)

Stott, K. G. 1984. Improving the biomass potential of willows by selection and breeding. In: Ecology and management of forest biomass production system. pp. 233-260. Sw Univ. of Agric. Sciences, Dept. Ecol. and Env. Res., Report no. 15.

Strong, D., S. Larsson and U. Gullberg. 1993. Discontinuous and continuous genetic variation in resistance to Salix viminalis L. to gall midge attack. Evolution 47 (1): 291-300.

Svärd, H. 1992. Recurrent selection for leaf area in Brassica rapa L. Sw. Univ. of Agric. Sciences, Dept. of Forest Genetics, Report 47, Uppsala. 40 p.

Thorsén, J., F.A. Aravonopoulos, P.E. Jorde, N. Ryman, U. Gullberg and L. Zsuffa 1993. Mode of inheritance and linkage relationships of isoenzyme genes in Salix viminalis L. Journal of Heredity (submitted).

Vahala, T. and T. Eriksson. 1991. Callus production from willow (Salix viminalis) protoplasts. Plant Cell, Tissue and Organ Culture 27: 243-248.

Vahala, T. and T. Eriksson, E. Tillberg and B. Nicander. 1993. Expression of a cytokinin synthesis gene from Agrobacterium tumefaciens. T-DNA in willow (Salix viminalis). Physiol. Plant. (submitted).

Vahala, T., P. Stabel and T. Eriksson. 1989. Genetic transformation of willows (Salix spp.) by Agrobacterium tumefaciens. Plant Cell Rep. 8: 55-58.

Verwijst, T. 1990. Clonal differences in the structure of mixed stand of Salix viminalis in response to Melampsora and frost. Can. J. For. Res. 20, 602-605. 